according to the principles of Soviet patriotism and proletarian internationalism".

These regulations are by no means simply a paying of lip-service to Party and ideology. In what promises to be a test case, refusnik Arkadii Tsinober is challenging the right of VAK to withold his Doctor's degree on the grounds that he is "amoral and unpatriotic".

Tsinober, who had worked at the Institute of Physics of the Academy of Sciences of the Latvian SSR for 15 years, defended his Doctoral thesis in the summer of 1975. Shortly after- wards, he applied to emigrate to Israel. At this time, although the new regulations of VAK had not come into force, their content was well known in Soviet academic circles, and dissidents were predicting that by 1985 no nonParty person would be able to hold a major academic or scientific post.

Tsinober's application for a visa was turned down on the grounds of the "secrecy" of his work on MHD-an excuse which might have appeared more valid had not his colleague and co-author Professor $\mathbf{H}$. Branover been allowed to emigrate. $\mathrm{He}$ never receive his Doctoral degree-and this, he claims is solely due to his desire to leave the country. Since the Soviet Union is a signatory to the Covenant on Civil and Political Rights, which guarantees the right of the citizen to leave any country, including his own, Tsinober claims that the refusal of his degree is unconstitutional, and is attempting to make good his claim through the Latvian courts.

In a recent message, he stressed that it is not simply a paper qualification that is at stake - that is a minor matter -but the whole question of state intervention in the academic process.

Vera Rich

\title{
New science policy minister for the Netherlands
}

AFTER a record breaking period of 206 days without government, the Christian-democrats and conservatives under Dr Dries van Agt as prime minister, finally came to power in the Netherlands at the end of last year. The new minister for science policy is Dr Rinus Peijnenburg, the right hand man of Dr van Agt during the days without government.

Formulating science policy will be a new area of government to Dr Peijnenburg. As well as being minister for science policy, he is acting as economic adviser to $\mathrm{Dr}$ van $\mathrm{Agt}$, who unlike most prime ministers is not an economist. Even though he has little knowledge of science and technology, Dr Peijnenburg's varied experience as a politician should prove useful in his new post.

During the formation of the new cabinet last year it was doubtful that the position of the coordinating minister for science policy would be strengthened. Recently, however, Dr van Agt has indicated that the science policy minister is to have more power and more money for running his department.

The organisation remains the same as in the previous cabinet. Responsibility for science policy lies with the department of education. Two ministers have some responsibility for science: the minister for education, who is concerned with science education in schools and universities, and the minister for science policy whose concern is science outside educational establishments.

With his other commitments, it remains to be seen how much time Dr Peijnenburg will spend on science policy. After a couple of months in office, however, he is taking his responsibilities for science very seriously and he may not have much time for his duties as economic adviser. $\mathrm{He}$ already has a science budget for 1978 which was allocated by his predecessor, Fokele Trip, who had been in charge of science policy for four and half years. The total budget for 1978 is 5.9 billion guilders of which 2.8 billion is to come from government funds (1.2 billion is to be spent in universities). Industry - mainly the five multinationals, Philips, Shell, Unilever, DAM and AKZO-will spend 3.1 billion. The percentage of the gross national product spent on the total scientific effort will remain at $2.1 \%$, the same as in 1977. This is the greatest percentage for civil research in the EEC after West Germany.

Dr Peijnenburg's science policy will follow along the same lines as that of Fokele Trip. Like Mr Trip, he will

\section{Biowarfare lab goes civil}

The Ministry of Defence's (MOD) Microbiological Research Establishment (MRE), Porton Down, is to be retained for civil research after 1979, the government announced last week. The illustration shows a category IV containment facility for microbiological research at Porton.

The future of MRE has been uncertain for more than a year. In the 1976 Defence White Paper, the MOD announced its intention to shed its responsibility for the establishment-where it has carried out most of its microbiological warfare research.

Last week, however, in reply to a question on MRE's future in the House of Commons, Dr John Gilbert, Minister of State at the MOD, said that the government had "decided to retain MRE as a civil establishment subject to satisfactory administrative arrangements being made" because it had "concluded that many of the capabilities and facilities of MRE represent a national asset of value".

Before "satisfactory administrative arrangements" are made, however, the $M O D$ will continue to "manage the establishment in 1978-79 and reduce it encourage technological innovation in small-to-medium-sized industry and has even promised a memorandum on innovation within a year. Other new activities include the setting up of a group to look into ageing research and a committee is to be set up to look into the state of biochemical research in Holland. A special group, linking various departments, will be established to advise the government on Dutch policy for space research and technology in the 1980s. In 1978 a decision will also have to be taken on the development of an extended version of the Fokker F-28 passenger plane at a cost of 200 million guilders.

Casper Schuuring

\section{Sorry, for copyright reasons some images on this page may not be available online}

to the size appropriate for the civil programmes now foreseen. This is expected to be about two-thirds of present strength". In the meantime "proposals for the transfer of responsibility from the MOD to the Department of Health and Social Security and the Public Health Service are under discussion". 